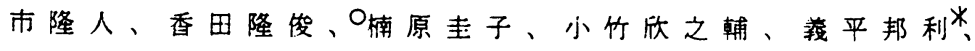
下村講一郎*、镰田博独三栄化学、国立衛試、筑波大米

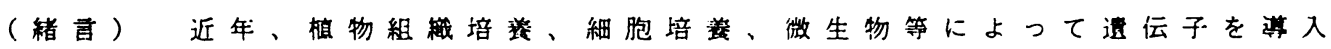
し形留变換させる技術等を用いて植物中の有用物留を生産する研究が多く行わ れており、工場レベルで大量に生産された例もみられるようになったが、その 生産物は必ずしも天然物と同一ではないということは既に報告されている。し かしそういつた人工的な生産物に関しての研究や安全柱の評価はまだ十分に行 われているとは言えない状況である。

（方法）そこで、本研究では、古来より染料に用いられている西洋アカネ を取り上げ、西洋アカネの莱よりりーフティスクを作成し、Agrobacterium rhizogenesをべクターとして感染させて誘導した毛状根をLS培地で継代培

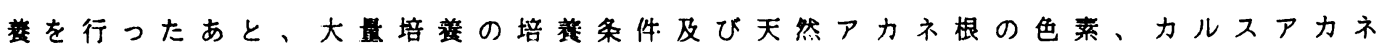
の色索との比較模討を行つた。

(結果) その結果、培荃条件については、0.5 1、101、1001の各ス ケールの中で毛状根の增殖率は1001の場合最も高く、またいずれにおいても 14日後以降に急速に增殖事が高まることがかった。また、得られた色秦を $\mathrm{H}$ PLCによって同定したところ、天然アカネ根中の主要色菜はカルス培妻色素 と毛状根色素においても珰めら扎たが、天然物に存在しない色案も認められ、

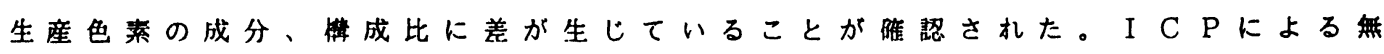
機元秦の分析では天然アカネ根の色慗と毛状根色秦に差は認めら扎ず、エイム ス法による突然变異原性試呀でも毛状根生産色秦に突然变異原性は認められな かった。

(考察) 以上より、毛状根による物筫生産はより有利に生産物を得られる 可能性があるものの、培羪条件によって生産される成分、椪成比に差が生して いることが考えられる他、天然アカネ根より得られる色秦と培㣀によつて得ら 机る色素に成分的に差があることがわかつた。天然アカネ根色素についても、 その産地、品種、抽出方法によつて生産物に差異が生しているという報告もあ り、生産色素の安全性評価はさらに慎重な涣討が必要であると思われる。 
○山本好和、木下靖浩、伊東威安、松永嘗、山田康之 (日本ペイント料技術センタ一、京大 ・農 ・ 細胞実験 センター・)

1. 目的

赤色色素を高産生するハナキリン培養細胞のその赤色色素成分が単一のアン トシアニンであることい、またその液体振璗培差による大量生産条件てについ ては、先の本シンポジウムで既に報告した。単一のアントシアニンを純品の形 で供給できることは、工業的に洒值のあることと考えられる。色素を工業的に 利用しようとする時、その化学構造の決定は重要であるが、本色素の場合、そ の色素の詳しい化学構造については不明であった。そこで、今回は色素の単離 精製とその化学構造の決定を目的として実験を行った。

2. 方法

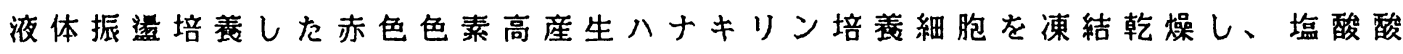
性メ夕ノールで赤色色素を抽出した。溶媒を留去して得た抽出物に水を加え、 ヘキサン、エーテル、酢酸エチル、ブタノールで順次抽出を行い各抽出物を得 た。赤色色素を含むブタノール抽出物を二回の分取逆相 H P L C に供し、単一 の赤色色素を単離した。得られた赤色色素、並びに、塩酸加水分解後得られた アグリコンと糖のそれぞれのクロマト解析、スベクトル解析を行い、その構造 を決定した。

3. 結果

この赤色色素を加水分解して得たアグリコンと糖は、標品との T L C、H P L C の比較分析によりシアニシンとアラビノースであることかわかった。また、 部分加水分解により、シアニジンに1個の糖が結合していること、また赤色色 素のSIM S 分析により分子量が419で、シアニシン骨格に五炭糖が結合し ていることがわかった。本色素のUVスペクトル分析では、各種のバラメータ

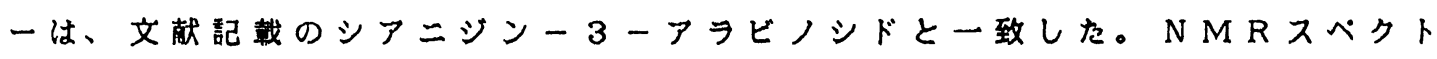
ル解析では、本色素は、シアニジンを骨格とし、糖はアラビノビラノースであ ることかわかった。以上の結果から、本色素をシアニジンー3ーアラビノビラ ノシドと同定した。本色素は、天然では非常に希な色素であり、培盖細胞での 単離は初めてのことである。

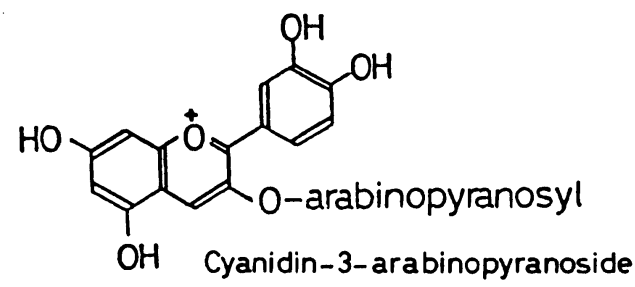

1)第 7 回植物組織培養シンボジウム講演要旨集、p21（1980）

2)第 10 回植物組織培養シンボジウム講演要旨集、p190（1980） 
熱帯産薬用植物のhairy root cultureによる昆虫脱皮ホルモン 生産

○田中伸和、松本 武 (ダイセル化学·総研)

我々はこれまでに、昆虫脱皮ホルモン(20-hydroxyecdysone: 以下20-HEと略)を生産 する植物の hairy root cultureを行い、シソ科植物Ajuga reptans var. atropurpureaでは、 1 月間に 500 倍以上增殖し、20-HE含量が $0.3 \%$ 以(母植物の約 6 倍)のクローンを得、 さらに1.5Lエアリフト型ジャーによる培養にも成功している1。

今回、いくつかの20-HE高含有植物に、国内産Agrobacterium rhizogenes MAFF0301724(ミキモピン型、pRi1724保有)を接種し、得られたカルス及びhairy rootの培鼠と 20-HE含量の検討を行ったので報告する。

アフリカ産木本薬用植物Vitex 属V. strickeri (乾燥根中の 20 -HE含量 $2.8 \%$ : 以下同 様)、V.doniana $(0.3 \%) 、 V$. madiensis $(0.7 \%) 、 V$. micrantha $(0.45 \%)$ 及びブラジル産多年

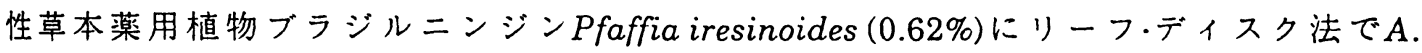
rhizogenesを接種した。同時に、非接種V.strickeri葉よりカルスを誘導した。

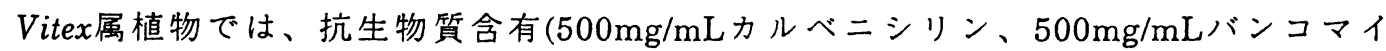
シン)無ホルモン・ムラシゲ・スクーグ(MS)培地上で培顕すると、A. rhizogenes 接種リー フ・ディスクからはgallが出現したが、hairy rootは誘発されなかった。除菌後、gallを 無ホルモンMS培地に移植すると、V.strickeriのみhairy rootが出現したが、5-10mm以 上は伸長しなかった。また、gallは無ホルモンMS培地上でカルス化し、よく生育し た。次に、hairy rootが出現したgall由来のカルスを $2 \mathrm{mg} / \mathrm{L} の \mathrm{NAA}$ 含有 MS培地で培举 し、カルスが1-2cmk生育後に、無ホルモンMS培地に移植すると、hairy rootが多数出 現した。さらに、カルスごとhairy rootを無ホルモン1/8MS培地に移植するとよく伸長 したが、カルスから切り離すと生育は止まった。カルス付きhairy rootの無ホルモン $1 / 8 \mathrm{MS}$ 液体培地での増殖は、1カ月で約3倍であった。なお、これらのgall由来のカルス 及びhairy rootでは、オパイン(ミキモピン)は検出されなかった。しかし、V. strickeri 葉より誘導したカルスでは、上記の現象が起こらないところから、これらのgall由来の カルス及びhairy rootは、A. rhizogenesによって形質転換した細胞由来であると考えら れる。今後、pRi1724のT-DNA領域2)とのハイブリダイゼーションを行う予定である。

一方、20-HEは、V.strickeriカルスでは認められず、gall由来のカルスで $0.00028 \%$ 、

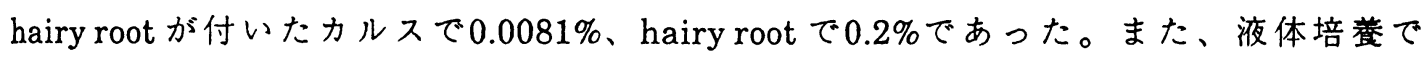

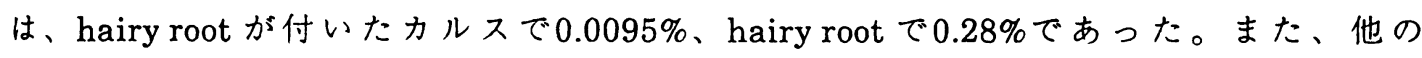
Vitex 属植物のgall由来のカルスでは、20-HEの存在は認められなかった。

ブラジルニンジンP. iresinoidesでは、hairy rootを誘発できたので、現在培養中であ る。

1)日本薬学会第109年会講演要旨集 p172 (1989)

2)日本農芸化学会1989年度大会講演要旨集 p155 (1989) 
。小林正洋、白川憲夫（中外製薬化成品研）児玉治、

赤塚尹巳（茨城大・農・㖘化）

目的：植物は病原菌の感染に対してさまさまな防湖反応を示すがその一つ にファイトアレキシン産生がある。イネではいもち病罪病葉からモミラクトン

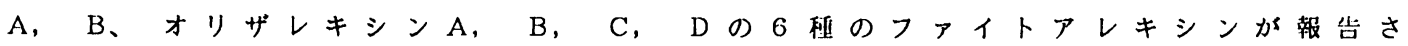
れている。そこで、㴼者らはイネ培䈍細胞におけるファイトアレキシンの痤生 誘導について検討した。

方法：イネ種子（品種 B L 1 ） を用いて $10 \mu \mathrm{M} の 2,4-\mathrm{D}$ を含むN 6 培地で䄧

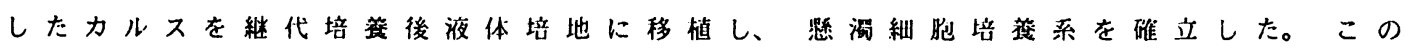
イネ慗湖培養細胞にいもち病菌（Pyricularia oryzae）接種や細胞壁分解瞵素 などの処理を行い、一定時間後にファイトアレキシンを抽出した。抽出は70\% メタノールで行い、ファイトアレキシン類はGC/M S - S I M 法により定量 した。

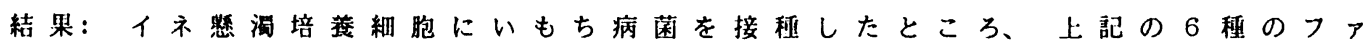
イトアレキシンが産生し、その産生量はモミラクトン類かオリザレキシン類に 比へて非常に多かった。ファイトアレキシンの産生量は接種したいもち病菌の レースにより翼なり、レース0 07 を接種した場合に最も産生量が多かった。 次に、いもち病菌の熟分解物を処理したところファイトアレキシンか隆生し、 このことからいもち病菌体内にファイトアレキシンを産生誘導するエリシター が存在することが推測された。また、数種の細胞壁分解醭素を処理したところ

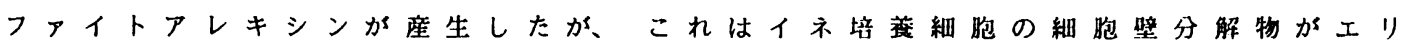
シターとして作用し、ファイトアレキシンの産生を誘導したものと考えられる。 さらに、レクチンの 1 種であるコンカナバリン $\mathrm{A}$ を処理してもファイトアレキ シンが産生誘導された。
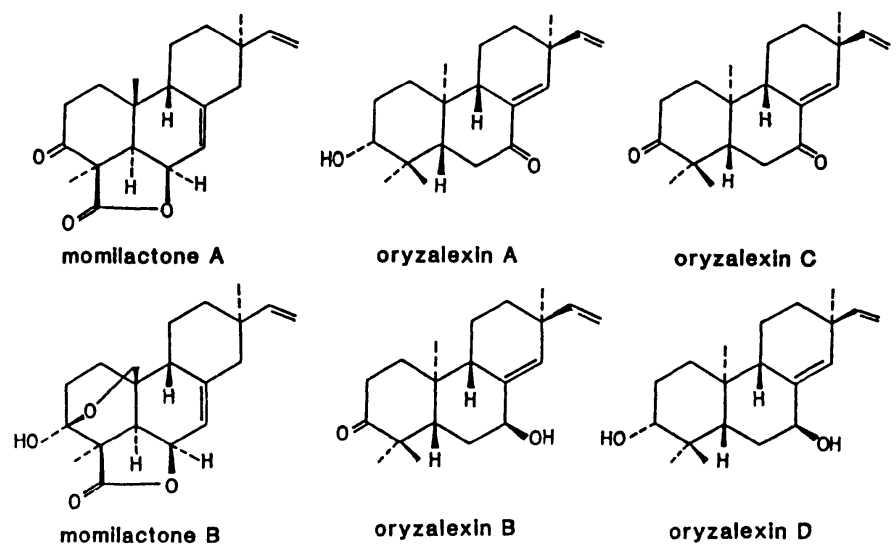
伊佐隆、小笠原健、金子浩子（キューピー (研究 所)

(序論) アストラガルス属植物は、ガムと称される天然增粘物筫（多 楼)を生産することで知られる植物である。殊にこの属の植物が造る、い わゆるトラガントガムは、アイスクリームやドレッシングに使われる産業 上重要な多栯だが、コストや安定供給といった観点から、最近では他のカ ムに置きかわっているのが現状である。そこで我々は、このガムを植物組 培食で得ることを目的に、種々検討した結果、トラカントカムそのもの でないがかなり粘性をもつ多堷を、当該植物毛状根培養によって得るこ とができたので、ここに報告する。

〔材料・方法) アストラカルスス属植物は、国立衙生武験所筑波薬用植

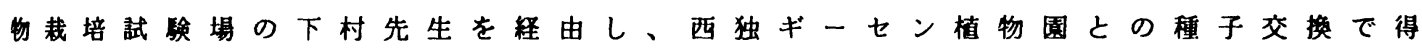
た。この種子を常法どうり減菌後、0.5 メのショ栯を含む寒天ゲル（ 0.9 风）上で、 $25{ }^{\circ} \mathrm{C}$ 明所で発芽させた。その後、実生をMS基本培地（0.25 \シェランガムで固化)に移植し、育成した植物の莱を道宜カルス化・毛 状根誘導に用いた。毛状根锈導に用いたアグロバクテリアはATCC 15834 と、筑波大学の鐮田先生より供与頂いた、干葉由来のN1AES 1724 のコ一 ド番号のAgrobacteriumrhizogenes である。バクテリアの培善はYEB培 地を用いた。感染は、インビト口植物の茎切断面に、一夜培養したバクテ

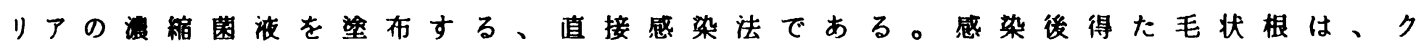
ラフォラン抗生物質 $(500 \mathrm{p} \mathrm{pm})$ で除菌した。得られた毛状根は、M S 基本 培地上、または液体培地中で回転培養した（60 r p m)。毛状根であること の確認は、銀染色法による才パインアッセイ法を用いた。カルス誘導時に 根が旺盛に增殖するホルモン組成が見つかったので、通常の培養根はI $\mathrm{A}$ $\mathrm{A}$ が $1.0 \mathrm{ppm}$ でぜアチンが $0.1 \mathrm{ppm}$ の M S 培地で培養した。

〔結果) 得られた毛状根を、液体培羪している間に、クローンによっ ては培地が非常に粘性をもつことが钼察された。しかし、通常の培羪根の 培湌では、このような現象は全く見られなかった。カルス・培養根・毛状 根を、それぞれ押しつぶすと、毛状根においてのみ非常に粘性の高い物筫 を吐出することも観察された。毛状根においても、クローン間のバラッキ が大きく、全くさらさらの場合と、押しつぶした薬匙がとれないくらいの 炶性を示す場合があった。現在、これらの物筫が何であるか確認中である が、今のところ目的のトラガントガムそのものではなく、もっと分子量の・ 小さそうな多栯であることが判ってきた。 


\section{只田伸一，岩橋康桑 (京大・莧)}

クチナシ Gandenia (G.) jasminoides の培蓄细胞は, IAA, Kinetin 添加MurashigeSkoog培地上て，母植物のイリドイド配糖体 geniposidic acid(2), geniposide (3), なラげに gardenoside (4) の他に, Tanenna属植物主イリドイド配糖体tarennoside (1)女生座する。コクチナシG.jasminoides var.radicans 及びその培喜細胞のイり

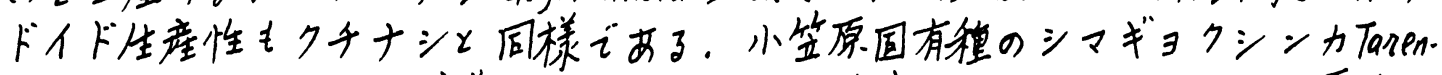

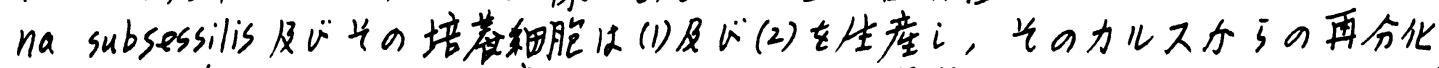

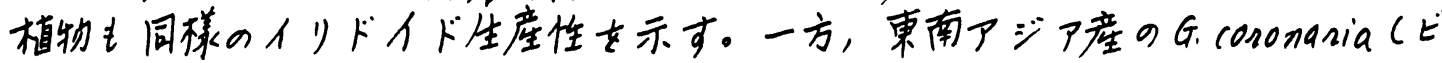

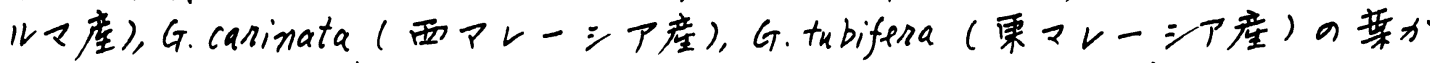

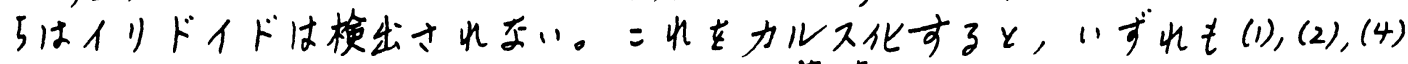

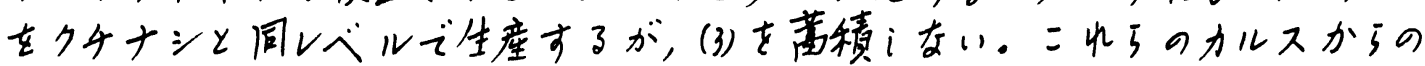

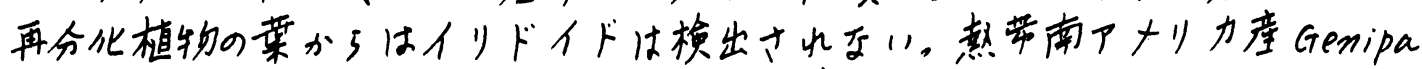

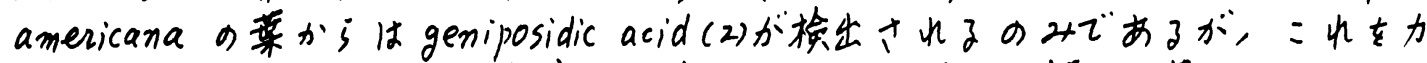
ル不化すると(1)（2），(4)を高率で生産する。光の再分化植物の某からは(2)が

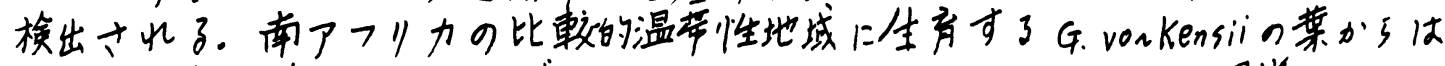

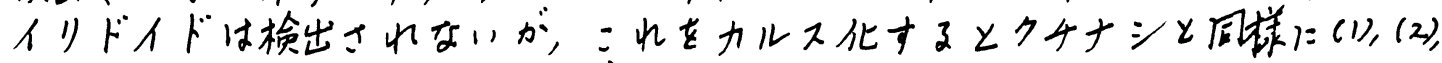

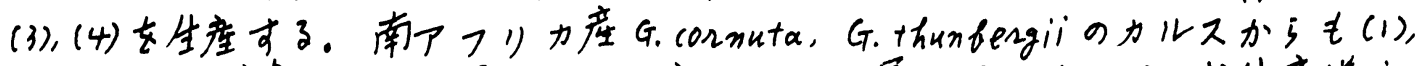

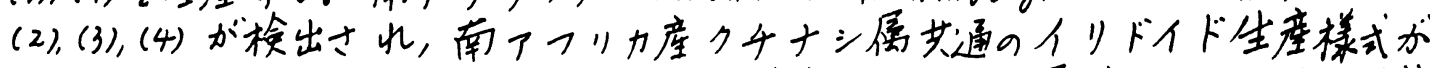
从られる。以上の铝果より，東アジア温带座のクチナシ属植物のイりドイド生

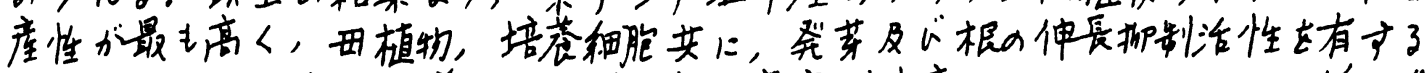

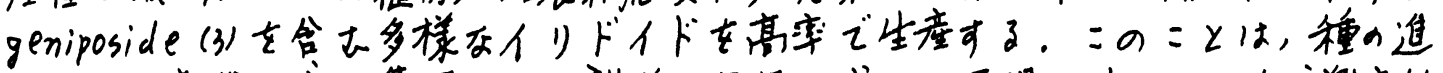

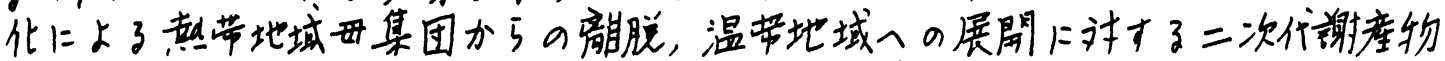

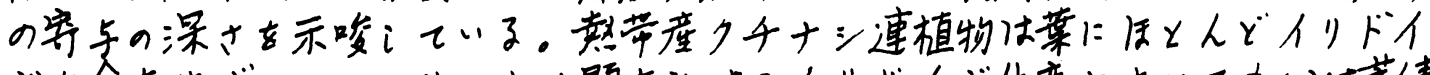

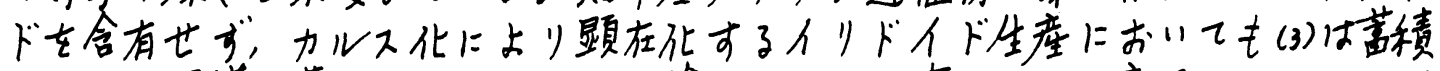

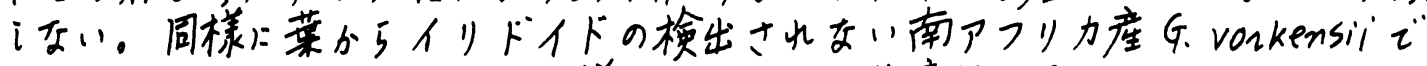
は、カルス化によりクチナシと同梯のイリドイド生座性を示す。才三ナェシ科の Valeriana 属等の植物のカルスは形能的朕分化がすす元とイりドイド生虐性方

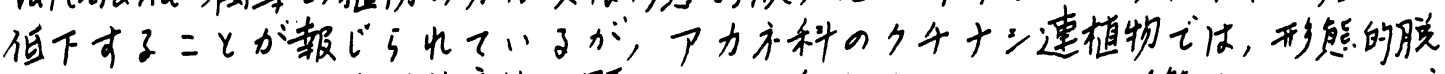
合化によりイリドイド生座性が矰在化え，向上することは，形熊分化と二次代

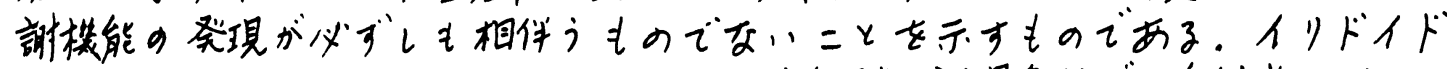

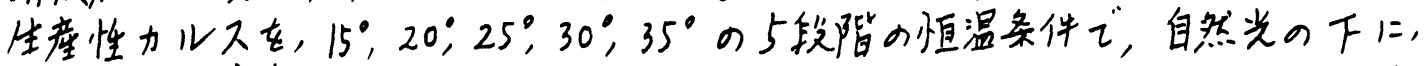

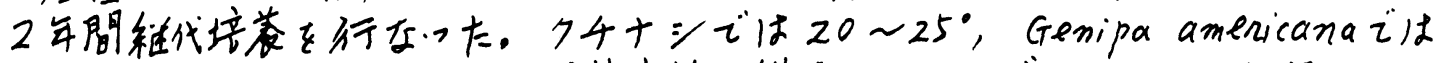

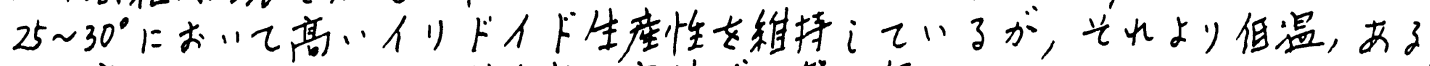
“は高温においてはイりドイド生座性が次第に但下する。これらのイリドイド

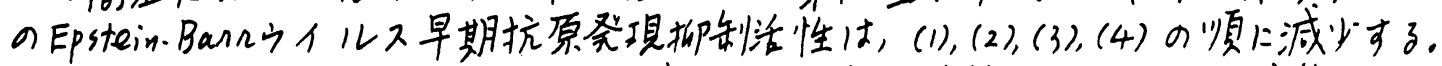

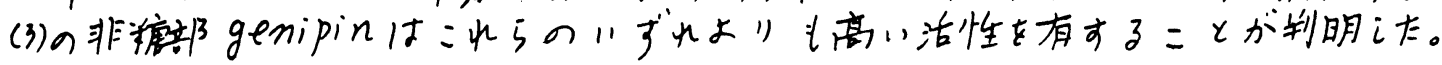


セイタカアワダチソウカルスによるプラシノライト様活性と培 筑条作

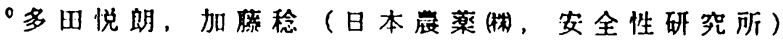

（目的）ブラシノライトは植物の細胞分裂および伸長生長を促進する作用を有し， 㖘作物への耐性付与，增収等ての利用か期待されている。先に我々は，调查した 62 種全 ての植物にブラシノライト様活性を認め，最も高活性のセイタカアワダチウ茎に含まれ る主活性物筑をブラシノライトと同定した。また7種植物カルスの中てセイタカアワダ チソウカルスが最高活性を示すことを報告したいここてはセイタカアワタチソウカル

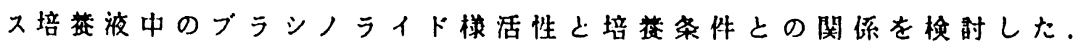

（方法）波体培䊓におけるセイタカアワダチソウカルスの增殖および培地中のブラ

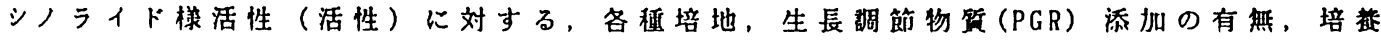

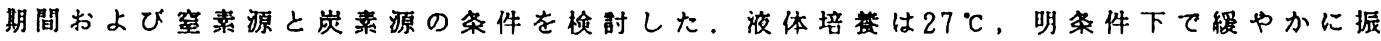
盕して行った。活性はコムギ莱身展開武禹

(結果) Auxin としてIAA, NAA, IBA むるいは2,4-D と, cytokininとしてbenzyladenine, methylmercaptopurine あるいはdihydrozeatine riboside との組合せては， 2.4-D $0.5 \mathrm{ppm}$ とbenzyladenine $0.3 \mathrm{ppm}$ て最も良好な增殖が得られた。 MS, White， Gamborget a1. あるいは Gamborg et a1. B5(B5)培地に书けるカルスの增殖はB5 培地 て最も良く，かっ細胞当たりて見た培地中活性も著しく漓かった。B5培地中の岸素源て はsucrose，glucoseおよびlactose の中てsucrose か，sucroseでは $2 \%$ が增殖および活

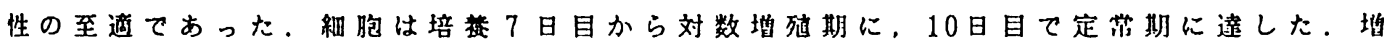
殖に伴う活性の变化を調へたところ，活性は細胞中に比へ培地中て著しく高く，培地中 活性は細胞の增殖にやや遅れて上萛し，14日目てビークとなった。培地中総窒素を一 定とし， $\mathrm{KNO}_{3}$ と $\left(\mathrm{NH}_{4}\right)_{2} \mathrm{SO}_{4}$ の瀑度 $(\mathrm{mg} / 1)$ の比を 2680/14-1500/792の轮四て変化させると， 增殖には大きな変化は見られなかったか，活性は湿度の比を2650/33とした場合最も高 くなった。活性ピーク付近の培 12 日目にNAA あるいは2,4-D とbenzyladenineをそれ それ10p pm 添加すると，1-2 日後に培地中活性は100-300倍高くなった。

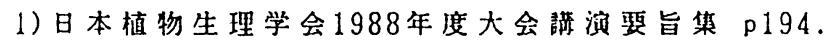

2)K. Wada et al., Agric. Biol. Chem., 49, 2249 (1985). 
1）目的ごまの種子中にはリグナン化合物、フェノール性化合物等が見いだ されており、これらの生理活性として抗酸化作用、抗変異原作用が認められて いる。種子中の油脂には酸化されやすい不飽和脂肪酸が多く含まれているにも かかわらず、酸化安定性に非常にすぐれている。このような特異性はごま種子 中に内存している抗酸化成分が酸素ラジカルによって誘導された脂質の酸化的 劣化を抗酸化的に防御しており、生体内での酸化的障害に対し重要な役割を果 たしていると考えられている。我々は黒ごまの種子ょり誘導し、得られたカル スに強い抗酸化作用を有する物質が含まれていることを見いだした。本報では 高温における液体培養での抗酸化性物質の生成について報告する。

2）方法 本実験には黒ごま種子より誘導し、継代培養(約22ヶ月)してきたカ ルスを用いた。液体培地はMurashige-Skoog (MS)培地を基本培地として增殖に 最適な組成に改変した。培養は振とう培養及び通気筧汼培養を行なった。培養 細胞中の抗酸化性物質は、エタノールで抽出後、吸着カラムクロマト及び逆相 HPLCにより得た。抗酸化活性の测定はリノール酸の空気による自動酸化反応を 追跡するロダン鉄法と生体モデル系として鬼赤血球膜脂質を過酸化物質により 酸化的障害を加え、その結果生じる脂質過酸化反応の抑制を指標とする赤血球 ゴースト法を用いた。

3）結果 培養温度によるホルモン類の要求性には変化がなく、カイネチンー 2, 4D $\left(10^{-5} \mathrm{M}, 8 \times 10^{-8} \mathrm{M}\right)$ の組合せにおいて $35^{\circ} \mathrm{C}$ で非常に早く增殖した。 $35^{\circ} \mathrm{C}$ 振 とう培䬭における最短世代洔間は $26.4 \mathrm{hr}(\mu \mathrm{max}=0.63 / \mathrm{day})$ であり、 $27^{\circ} \mathrm{C}$ 培養の 約2倍の増殖速度であった。 $35^{\circ} \mathrm{C}$ の高温度での植物細胞培養の報告は見当たら ない。高温度培養で得られた培養細胞の抽出物には強い抗酸化活性が認められ た。一方、ごまは熱帯原産植物として遺伝的に高い温度を好む性質が維持され ているものと考えられ、細胞内に抗酸化性物質を蓄積し、これによって温度、 光、紫外線、酸素ラジカルなどから細胞障害を防御していると推察される。
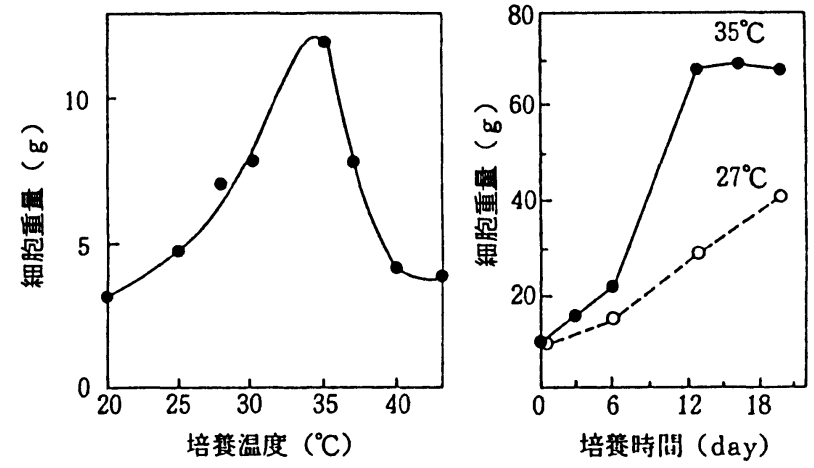

ゴマの培細胞の增殖と温度（固体培地）

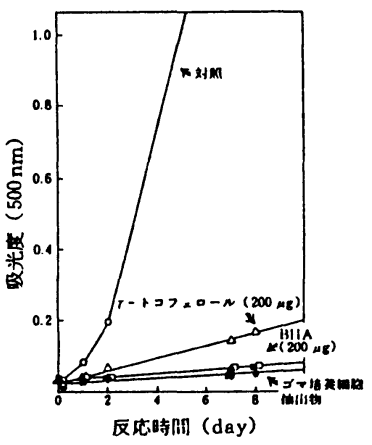

ゴマの培爰䎩胞抽出物による リノール酸の自動酸化の抑制 
鍋田害助，箭田浩士，波多野清美，奥山寛（带音大・

農化)

1. 目的カラマッ( Larix leptolepis) 実生か5誘導したカルスは、モノテ ルヘン、セスキテルペンを蓄積するが、含有量も低く、また生成するセスキテ ルペン類の種類も少ない。生成する $\alpha$-cedrene及び $\beta$-farneseneに関しては、 重水秦で特殊㴔識したメバロン酸投与実験で、その生成機構を明らかにした。

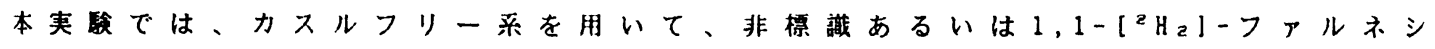
ルピロリン酸からのセスキテルペン生成を試み、カラマッカルスが潜在的に有 する、セスキテルペン生成能を明らかにすることを目的とした。

2. 方法カラマッ緑色カルスを、ポリピニルピロリドンを加えた0.05 Mリン

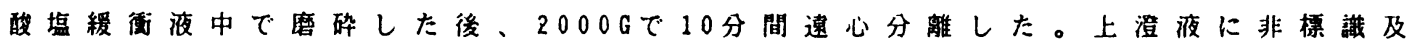

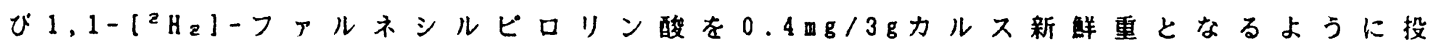
与して、 $25^{\circ} \mathrm{C}$ 、暗所で 24 時間インキュベートした。エーテルで抽出し、抽出夜 をGC/MS分析に供した。

3 . 結果実駼に用いたカラマッカルスは、炭化水素系セスキテルペとして longifolene、 $\alpha$-cedrene、 $\beta$-cadinene、thujopseneを、含酸素系テルヘンと して数種のセスキテルペンアルコール及びß-ironeを生成する。このカルスか らのセルフリー系によりファルネシルピロリン酸から生成した炭比水慗系不 キテルヘンとして、 $\alpha$-cedrene (Fig中ピーク1)、 $\alpha$-farnesene (2)、 $\beta$ hi machalene (3)、 $\beta$-farnesene (4)、acoradiene (5)、B-bisabolene (6) 加同定 され、その他14個の未同定炭化水素の存在を確認した。1,1-[²Ha]-フアルネシ ルピロリン酸を投与したものでは、炭化水素系セスキテルペンの分子イオンピ

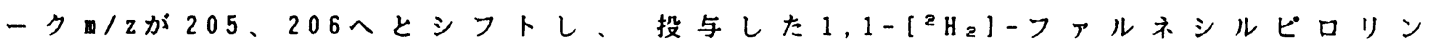
酸から誘榇されたものであることが示された。また、同定された重水素標㖪 himachalene ( $\left.\mathbf{H}^{+}, \mathbf{m} / \mathbf{2} 205\right)$ では懪化の際に 1 位の重水素 1 個が脱離すること が確珰された。

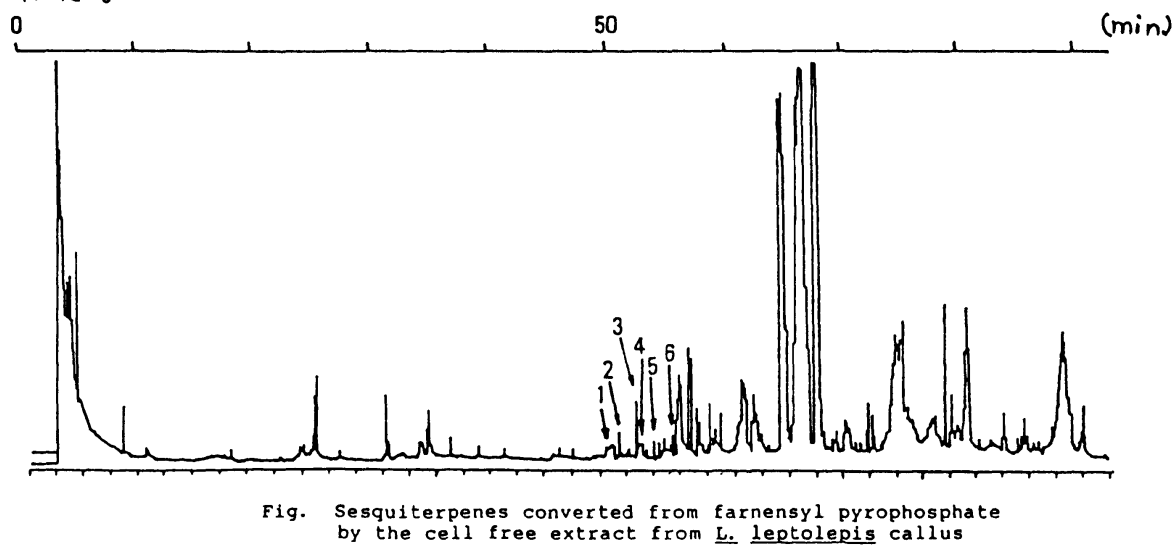


○家田京子、山本浩文、田中稳幸、飯沼宗和、

水野瑞夫（岐阜薬大・生薬）

（目的）古くから淫羊笽として、強精・強壮を主な目的に用いられているメ ギ科（Berberidaceae）イカリソウ属（Epimedium）植物の成分研究の結果、 anhydroicaritin およびその des-0-metyl 体をアグリコンとする 20 数種のコ レニルフラボノール配糖体が報告されている。また北アメリカに自生するアメ リカイカリソウ属の一種 Vancouveria hexandra の成分については、アグリコ ン部分は Epimeduim 属と同一で、構成糖に差異のみられる数種のブレニルフラ ボノール配榶体を単離、構造決定した。 Epimeduium 属および Vancouveria 属の培圽練胞での、ブレニルフラボノール配糖体生産に関する研究の一環とし て、今回は $\underline{V}$. hexandra の上記配糖体の生産について検討した。

（方法） Vancouveria hexandra Morr. \& Dcne の葉の切片加ら 2,4-D $3 \mu \mathrm{M}$ 、 kinetin $5 \mu \mathrm{M}$ を含む Linsmaier-Skoog (LS) Gellan gum 培地にて $25^{\circ} \mathrm{C}$ 、明 所（16 時間/日）でカルスを誘前し、28 日毎に同一条件下で 1 年半継代を行 つた。得られたカルス（新鮮重量 $368.8 \mathrm{~g}$ ）を逨結乾燥後、メタノールで加熱 還流抽出し浀縮してエキス $9.7 \mathrm{~g}$ を得、シリカゲル、Sephadex LH-20 および 逆相カラムクロマトグラフィーを繰り返して分離精製を行った。また生産量は 細胞をメタノールで 4 時間加熱還流抽出した後、逆相の HPLCにより定量した。

（結果） 得られたエキスを TLC およU゙ HPLCにより分析した結果、10 種以 上のフラボノール配糖体が含まれることが明らかになった。このうち 2 つの化 合物を単離し、MS, 1 H-NMR, TLC, HPLC よりそれぞれ anhydroicaritinをアグ リコンとする配結体 icari in (12 mg) 、hexandraside A (4 mg) と同定した。 HPLCによる定量の結果、カルス中にはそれぞれ乾燥重量当り $0.12 \%$ ０.09％ 含まれていることがわかった。なおこれらの成分は、植物体の地上部にそれぞ れ約 $0.3 \%$ ０.2\% 含有されている。またフラボノール配糖体生成の経時变化 を追った結果、成分は細胞の成長に忘じて增加するが、定常期に入ると減少す ることが明らかとなった。カルス中に含まれる他のブレニルフラボノール配糖 体の単離構造決定、および培羕条件の変更によるブレニルフラボノール配榶体 の生産性の向上に関しては、現在検討中である。

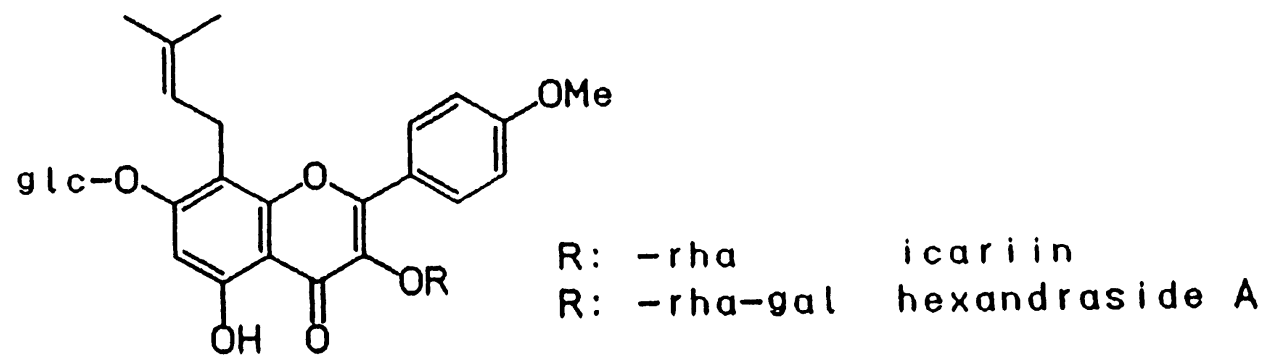


藤田暒, 㚼本均, 高藤傾一, 中里溥志（雪印乳業 - 技研)

1.目的メグスリノキ（Acernikoense Maxim.）は, 宮城県以南の山地に 自生するわが国特産のカエデ科の落葉高木で，古くから樹皮や葉を前じて洗眼 薬として用いられ，現在では肝疾患に対する民間薬として用いられている。わ れわれは，有用なメグスリノキ成分を生産する目的でカルスを誘導し，その生 産成分の分画を行った。また，生物変換による(t)-rhododendrolおよびその配 䌅体の生産についても検討したので，得られた知見について報告する。

2. 方法栃木県産メグスリノキの葉・葉柄・枝から常法によりカルス誘㐿 を行った。基本培地にはMurashige\& Skoog 培地を用い，植物ホルモンはオー キシンとして2,4-D，NAA，IAA， IBAを、サイトカイニンとしてkinetin, BA, 4PU30, Zeatin, Zeatin riboside, 2 i p を, 単独あるいは組み合わせて 種々の漊度で用いた。成分分画については，まず，東結乾燥したカルスをメタ ノールで温浸した後，溶媒を留去して得た抽出物に水を加え，シエチルエーテ ル，酢酸エチル，五フフタノールで順次抽出を行った。次に，各溶媒可溶部につ いてシリカゲルカラムクロマトグラフィーを絽り返し行った。生物变換につい

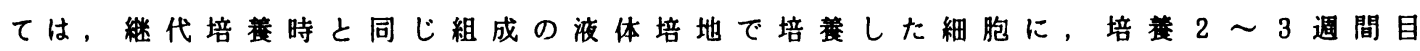
に基質となる化合物を添加しさらに1週間培養した。培養終了後培地と細胞 を分離し，細胞は成分分画と同様に処理した。培地は，ジェルエ一テル，酥 酸エチル，龷ーブタールで順次抽出を行った。なお，成分の同定は，標品との TLC・HPLC等での比較, GC-MS 等で行った。

3 . 結果いずれの植物ホルモンの組み合わせにおいても，カルスが得られ た。オーキシンとしてNAAを用いた場合のカルスは，增殖が良好であった。 2,4-Dを用いた場合のカルスは，增殖が遲く，継代を続けるうちに褐変死した。 $N A A$ を用いて得られたカルスの中で，特に增殖の速いNB-R株 (NAA10-5 M, BA

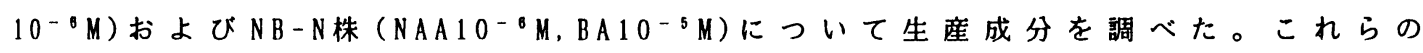
株は，原植物樹皮の成分である $\beta$-sitosterol，scopoletin，(t)-catechinお よび (十)-rhododendrol配糖体を生産した。なお, ラット四塩化炭素肝障害に対 して防護効果を有する(t)-rhododendrolはい，生産されなかった。

このため, 生物変換による $(t)$-rhododendrolおよびその配糖体の生産を武み た。NB-N株を用い，基質として4-(p-hydroxyphenyl)-2-butanone (HPB)， coumaric acid, dihydro-p-coumaric acid およびdihydro-p-coumaryl alco一加を添加したところ,これらの物質は培地中から消失し、HPBについては rhododendrolを経てその配糖体になることがわかった。
1）篠田ら
生薬学雑誌
40 (2) $177 \sim 181$
$(1986)$ 
○滰口好司・小西裕和・大里克明・星野卓二・・浜田博喜 (日揮・生物工学研、岡山理大・理・生、“网山理大・理・化)

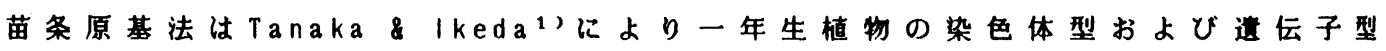
の保存方法として開発されたものであり、多年生植物にも通用できることが報 告されている。

苗条原基は遗伝的に事めて安定であり、かつ增殖事が高く、また植物体への 転换む容易であるため、植物のクローン化や大量增殖など有種面での利用加期 待されているが、さらに二次代溯座物の生産む示唆されている。

そこて、我々はカワラヨモギ（Artemisia capillaris）の苗条原基による有 用物筫生産の可能性を梌封した。カワラヨモギにはキャビレン，キャヒリン， キャビラリン，キャビラリシン，スコバロンなどの有用物筫が含まれているか、 今回は菜理作用の知られているキャビリシンに注目して二次代㽎産物の生成 条件検赫を行った。

カワラヨモギの苗条原基は茎頂点から $\mathrm{M} \mathrm{S}^{2}$ )培地（NAA=0〜0.02 mg/\&、BAP= $0.2 \sim 2.0 \mathrm{mg} / \ell)$ て光照射下、回転培甆することによって落された。そのう ち、 $N A A=0, B A P=2.0 \mathrm{mg} / \&$ 条件が最むよく、增殖速度は倍化時間（Td）で 2 日とかなり速かった。この条件.で培竞した苗条原基の精油成分を测定したとこ ろ、キャビレンが検出された。カワラヨモギのカルスでは全く検出されていな いため、苗条原基は極めて植物体に近い性筫を有していることが判明した。し かしなからキャビラリシンについては検出されなかった。

そこで苗条原基を $\mathrm{MS}$ 培地でオーキシンを NAA=0〜1.0 mg / \&、2,4-0=0〜1.0 $\mathrm{mg} / \ell 、 \forall イ ト カ イ ニ ン を B A P=0 \sim 2.0 \mathrm{mg} / \ell 、 K=0 \sim 2.0 \mathrm{mg} / \ell$ に変化させて培恙 を行った。その結果、キャビラリシンかわずかに検出された条件はあったもの の今回の条件跁囲ではほとんど検出されず、さらに広筙な培地おょびホルモン などの模封が必要となった。

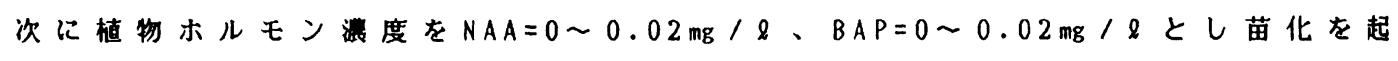
こさせる条件で培養を行ったところ、マルチブルシュートではキャビラリシン は生成されなかったが、寒天に移しマルチブルシュートから幼植物体が形成さ れた段階では成植物体と同程度のキャビラリシンが含まれていた。

この結果、苗条原基の增殖速度と再分化能をうまく利用することによって効 弯よく有用成分を生産できる可能性が示唆された。

\footnotetext{
1) R.Tanaka and H.Ikeda Jpn.J.Genet.58:65-70(1983)

2) M S : Murashige\& Skoog培地
} 